\title{
Foreword by Henry Brown and William Brown
}

\section{ARTHUR BROWN AS A PRIVATE PERSON}

All children have perspectives on their parents that are unique in both strengths and weaknesses. Kenneth Button has provided a fine account of the intellectual journeys of our father which were the background to our growing up; but it was a background of which we were only casually aware. For us he was simply part of the family. It is an interesting challenge to disentangle some memories that might provide the reader of this book with a fuller picture of Arthur Brown, beyond the academic economist.

A good starting point is with our mother, Joan. A clergyman's daughter from Lancashire, she was a classics scholar at Oxford when they met. It was a reflection of her strength of mind that, despite the college rule that it would deny her a full honours degree, they married while she was still an undergraduate. Their three sons were born in Oxford during the War while he worked in London, and at its end the family moved to Richmond upon Thames. In 1947 we settled in the house in Leeds where they lived for the rest of their lives. She looked after the home and family. Building on her love of its literature, she taught herself Russian, taking a degree in 1963 and then becoming a teacher of Russian and Latin at Leeds Girls' High School. Our parents were totally devoted to each other, and she was a constant support for him. Their mutual support was especially important when, in 1959, the family was devastated by the death of our eldest brother, John, in an accident in the Swiss Alps at the age of 19.

Home was a large house built in 1912 with an acre of garden, much of it woodland, on the edge of the Meanwood Valley. Until long after we left there was no television in the house, but ever-growing shelves of books on a great variety of subjects. Our parents were both keen gardeners. For our father 'the great thing about a garden is that it is always working with you', and 'the wonderful thing about gardening is that you almost always get more done than you expected'. It was the focus of his weekends and one reason why he kept physically fit, because a large and varied garden demands constant manual work. As children, the garden gave us considerable freedom from parental supervision. We were free to climb trees and 
dig dens - and later learn more constructive skills such as the use of axes, bowsaws and scythes. As they grew older, our parents beat a careful strategic retreat from the garden, allowing it to become ever more jungle-like, with massive rhododendrons, climbing roses and resident foxes.

A distinctive feature of the family was that neither parent ever learned to drive. They both liked walking, and Leeds had a good public transport system. This meant we were not to become familiar with the nearby Yorkshire Dales until later in life. Having no car shaped our holidays, always reached by railway. Twice a year for as long as they were alive we would stay with our paternal grand-parents who had retired to a village near Prestatyn, Wales, wonderfully close to both the beach and hilly countryside. Each August we would go, by the memorable Settle-Carlisle line, for two weeks in a hotel near Loweswater in the north-west Lake District. There we walked the fells and messed about in rowing boats on Crummock Water. Our father greatly enjoyed making holidays creative and useful as well as fun, which ensured we became adept with maps and, for example, with drawing little graphs that plotted the distance of a walk against altitude. Even on holiday his love of back-of-envelope calculations never left him. In remote spots, in miserable weather, his 6-inch slide-rule would be brought out to resolve a debate about the weight of water passing over a weir, or the number of trees in a plantation. Loweswater became a home from home for our parents, who returned there, usually twice a year, until infirmity intervened nearly fifty years after their first visit.

In some ways our father filled the conventional paternal role of the 1950s. He would get up after we had left for school and return from work after we had finished tea. But he was not a remote parent. He took great interest in our enthusiasms and hobbies. Given the time, he would join us listening to, for example, The Goon Show and Tom Lehrer. His mildly bawdy sense of humour was never far away. He was an enthusiastic photographer, which in those days meant color transparencies viewed on a screen in a darkened room. These were always great family occasions, full of conversation, whether the pictures were of a recent holiday or from his own increasingly exotic trips abroad for work. Later we were sometimes to travel with him, and he delighted in sharing with us the associated sights and discoveries. On visits home, after we had left, it is the long conversations that come to mind. These were never about gossip or ephemera. He was always interested in discussing what we and he were doing and reading and thinking, and about major events in the world around us.

A soft-spoken man, he probably came over as rather shy. Perhaps he was slightly intimidating because he was not strong on small-talk and was impatient of what he perceived as folly. He was genuinely modest, and had mixed with the Great and Good sufficiently to be rarely impressed. Beyond 
the family, his closest friends were from among his academic acquaintances, past and present. His times in the States provided lasting American friends, and he remained a loyal reader of the New Yorker all his life. His reading was very broad. He kept his early interest in science alive with a regular subscription to the New Scientist. Although he did not share our mother's interest in fiction, he retained his youthful affection for Jane Austen, Conan Doyle and pre-war detective writers such as Dorothy L. Sayers. He preferred to read fact-based material - travel writing, modern history and biographies. He maintained a lively interest in the visual arts, rarely missing an exhibition in London if it could be fitted into his regular trips there.

Perhaps least evident to others was his love and knowledge of both English and German poetry. In his youth he had read a great deal and, having an extraordinarily retentive memory, he remembered a great deal. It was fascinating to watch him slowly dredge up from his memory whole verses, prompted by some passing poetic quote. Wordsworth was a favorite. When he was away from home, living in the States, he and our mother had worked their way through the Shakespeare sonnets together, week by week, by airmail letters. He returned to reading poetry after his retirement. It was partly the conciseness of good poetry that appealed to him. He was disparaging of grandiose waffle. He took delight in applying what he called his 'reversal test': does a given statement sound equally plausible if you insert a negative in it? His passion for evidence may lie behind his ceasing to be religious at some point in his late twenties, despite that religion remained important to our mother. It was also a reason for his never becoming politically involved, despite being politically well informed. He found the world intensely interesting, and the challenge for him was to understand it.

Henry Brown and William Brown

July 2017 
Kenneth Button - 9781786433664 Downloaded from PubFactory at $04 / 26 / 2023$ ०3: $\odot \odot: 43 P M$ via free access 